\title{
Mobile Payment Products in Indonesia: Is it a Lifestyle or a Need?
}

\author{
Auditia Setiobudi ${ }^{1}$, Christina Sudyasjayanti ${ }^{2}$, Kevin Julianto Singgih ${ }^{3}$, and \\ Aiman Fauzi Gadi ${ }^{4}$
}

\begin{abstract}
:
Research aims: This study aims to explore consumers' preferences and perceptions of the use of mobile payments in Indonesia.

Design/Methodology/Approach: This study used a comparison of Cronbach's Alpha and Cronbach's Alpha if Item Deleted to find items preferred by mobile payment users. Factor analysis was employed to get consumers' perceptions of using mobile payment.

Research findings: The results of this study found that consumer preferences for the use of mobile payments were compatible with their needs, helped complete work/needs, were used by the social environment, were easy to use, and made consumers happy. Meanwhile, consumers' perceptions of mobile payment were formed from three factors: perceived ease of use, intention to use mobile payment, and mobile payment self-efficacy.

Theoretical Contribution/Originality: This study examines the use of mobile payments in Indonesia further.

Practitioners/Policy Implications: Mobile payments are not only a lifestyle because the products' benefits are increasingly numerous and varied.

Research Limitations/Implications: This research was only conducted in Java. Keywords: Mobile Payments; Preferences; Perception; Factors
\end{abstract}

AFFILIATION:
1,2,3,4 International Business

Management, Universitas Ciputra,

East Java, Indonesia

*CORRESPONDENCE:

auditia.setiobudi@ciputra.ac.id

THIS ARTICLE IS AVAILABLE IN:

http://journal.umy.ac.id/index.php/mb

DOI: $10.18196 / m b . v 12 i 1.9440$

\section{CITATION:}

Setiobudi, A., Sudyasjayanti, C., Singgih, K.J., \& Gadi, A.F. (2021). Mobile payment products in Indonesia: Is it a lifestyle or a need?. Jurnal Manajemen Bisnis, 12(1), 115-126.

\section{ARTICLE HISTORY}

Received:

23 July 2020

Revised:

01 Sep 2020

05 Dec 2020

Accepted:

19 Dec 2020

\section{Introduction}

The wireless telecommunications industry in Indonesia is increasing rapidly. The needs and development of features offered are also increasingly diverse. The outcomes of research conducted by Wearesocial Hootsuite in January 2019 have proven this growth. In 2018, the number of internet users reached 132.7 million. This amount increased to 150 million internet users or $56 \%$ of the total population, with 355.5 million telephone users in 2019. As for 2020, Indonesian internet users reached 175.3 million, or $64 \%$ of Indonesia's entire population. The majority of these users used mobile phones, as many as 171 million or $98 \%$ of Indonesian internet users. This user growth has reached $21 \%$ per year for the recent five years. According to Hootsuite and Dailysocial research in 2020 , Indonesians who used the internet had an average age of 16 to 64 a day, reaching an average of 7 hours 59 minutes. This large population and the rapid growth of internet and telephone users have become a potential and possibility for the national digital economy. 
The beginning of emerging e-commerce, online transportation, online stores, and payments that can be performed online is proof of the evolution of the digital economy through the usage of mobile phones.

Mobile phones are starting to develop into many models and diverse features nowadays. These developments also affect the usage of mobile phones/smartphones that are getting gradually varied. There are innovations in the progress of digitizing payment transaction instruments and financial services. Payment systems innovate from conventional payment systems through debit cards or credit cards into digitizing payment systems through electronic money (Manik, 2019). Mobile phones can directly be a medium that can substitute the role of physical money and credit cards. Mobile phones can also be used for purchasing and trading transactions that are both micropayment and macro payment. This kind of engagement is known as mobile payment.

Mobile payment makes it easy for mobile phone owners to carry out economic activities such as fund transfers and transactions. The cell phone owner simply has a telephone credit deposit or a deposit in the form of a fund deposit in a supported application. The deposit can function as electronic money (e-money), which can be used for transactions and payment instruments. In 2007, electronic money began to grow through the banking sector, which issued products in the form of mobile payments (Alfany, Saufi, \& Mulyono, 2019). Fintech services are considered convenient to transact online and offline in only one platform, the mobile payment application. The activity is carried out without making an account at a particular bank. Besides, e-wallet applications increased by $50 \%$ from Q4 2017 to Q2 2019. E-wallet product development is a boost from the Financial Services Authority to improve economic growth in Indonesia.

Mobile payment services in Indonesia have grown in popularity as smartphone usage has reached $70 \%$ in the last five years. There are more and more e-wallet application choices without a card for transaction. Bank Indonesia data inform that 38 e-wallets have received official licenses. In 2018, e-wallet transactions in Indonesia reached USD 1.5 billion. The e-wallet application serves as a cashless solution in Indonesia. Based on 2019 Q2 data and the number of application downloads, the local e-wallet application managed to occupy the top 5 rankings with Go-Pay in the first place, OVO in the second position, followed by third-ranked DANA, LinkAja in fourth, and iSaku in fifth.

Hastomo and Aras (2018) state that the payment system's transition from cash to debit or credit cards is called the concept of a cashless society. According to Juhri and Dewi (2017), the existence of a cashless society allows technology to improve its quality for the community, but not all new methods can be taken by the community easily. In this case, consumer preferences are consumer attitudes towards product brand selection, formed by assessing various brands in the various options available. Meanwhile, perception is a process whereby individuals organize and interpret sensory impressions to give purpose to the environment. In this research, the choices and brands to be evaluated were four of the most downloaded e-wallet products and have been the largest number of monthly active users in seven quarters since 2017 on Google Play and iOS. Based on information from App Annie Q2 2019, the top four e-wallet apps referring to the size of their monthly 
active users were all local-based e-wallet app: Go-Pay, OVO, DANA, and LinkAja. Hence, this research was conducted based on the phenomenon of using more diverse mobile payment applications to determine the aspect forming the preferences and perceptions of selections further. This study aimed to explore consumer preferences and perceptions of the use of mobile payments in Indonesia.

\section{Literature Review and Hypothesis Development}

\section{Literature Review}

Financial literacy will influence how people save, borrow, invest and manage finances further, financial skills here also place more emphasis on the ability to understand the basic concepts of economics and finance, to how to apply them appropriately Widdowson and Hailwood (2007). Research conducted by Hogarth (2002), shows that people who have a higher level of financial literacy tend to be better at managing finances including investing in various types of financial products. Financial ability is the ability of a person to solve a problem or manage his finances, whether obtained from salary or pocket money which means referring to the economic situation where the situation will affect product selection and purchasing decisions for a particular product (Kamil, 2020).

Financial technology is a financial service that is currently developing. Bruggink and Mouilleron (2016) stated that finance technology (Fintech) is an effort to facilitate innovation in financial services by utilizing information technology. Furthermore, Campenon (2016) added that Fintech would be an essential role as a disruptive innovation in financial services. Marakarkandy, Yajnik, and Dasgupta (2017) uncovered that bank initiatives and internet use efficacy were significant factors determining internet banking's self-efficacy. Besides, government support and bank initiatives positively affected trust, while risk perception had a negative effect. The use of the internet and internet banking's self-efficacy positively influenced perceived convenience; perceived convenience and bank initiatives positively impacted perceived benefits. Perceived benefits, perceived convenience, the efficacy of internet use, and trust contributed to attitudes towards internet banking use; attitude, perceived usefulness, and self-efficacy of internet banking contributed to behavioral intentions; perceived behavioral intentions and risks were associated with actual use.

According to Juhri and Dewi (2017), the existence of a cashless society allows technology to make it easier for the community, but not all new technologies can be accepted by the community easily. The process of accepting technology requires time and adjustments to daily habits. Even so, a cashless society can make it easier for users to carry out various types of transactions via personal cell phones, such as purchasing goods or services and various other services. Also, the use of electronic cashless services can provide many benefits to users. These can be categorized into perceived usefulness according to the Technology Acceptance Model (TAM) theory. This issue is in the spotlight of researchers on public confidence in new technology and acceptance of technology using the Technology Acceptance Model (TAM) theory developed by Davis (1989). 
Moreover, varying human behaviors are described in various complex intention models, but not all models can explain a behavior correctly. Therefore, many researchers create some models and representations of information technology acceptance to understand the factors in the use of information technology. Based on UTAUT theory, perceptions of technology performance, the anticipation of the learning, the influence of superiors and peers, and the condition of technological facilities are factors that shape the intention to use technology (McLeod \& Pippin, 2012). Based on research by Singh, Srivastava, and Sinha (2017), which developed a conceptual model to test various factors influencing consumer satisfaction in Northern India, it used the integrated UTAUT model to test consumer intentions from Shin (2009) and additional factors (hedonism). Singh's research objective was to determine the relationship between preferences, perceptions, usage, and customer satisfaction. The results revealed a significant relationship between perceptions, usage, preferences, and customer satisfaction. Besides, safety, hedonism, and trust were some of the most influential variables in the study.

Some variable used in this research are:

1. Perceived behavior control (X 1.1 and $X 1.2)$ reflects the perception of internal and external constraints on behavior and includes self-efficacy, resource promotion conditions, and technical conditions (Venkatesh, Morris, Davis, \& Davis, 2003).

2. Perceived usefulness $(X 2.1)$. It is the degree to which a person believes that using a particular system will enhance job performance (Venkatesh et al., 2003).

3. Extrinsic motivation (X 2.2). It is the perception that users' willing to perform an activity. Achieving valued outcomes distinct from the activity itself, such as improved job performance, pay, or promotions (Venkatesh et al., 2003).

4. Ease of use $(X 5.1, X 5.2, X 5.3, X 5.5$, and $X 5.6)$. This variable refers to the degree of innovation that is difficult to use (Venkatesh et al., 2003).

5. Job-fit (X 2.3). It refers to the system capabilities to enhance an individual's job performance (Venkatesh et al., 2003).

6. Use behavior (X 6.1). It refers to a continuous commitment to the product. Users will be more likely to adopt mobile commerce if they feel that it can help them conclude transactions at any time, in any place, and is easy to acquire and easy to use (Park, 1998; Bhatiasevi (2016).

7. Intention to use systems (X 6.2 and $X 6.3$ ). It is the user's willingness to use the system (Mardiana, Tjakraatmadja, \& Aprianingsih, 2015).

8. Intrinsic motivation $(X 8.1, X 4.1)$ is defined as the perception that users want to perform an activity for no apparent reinforcement other than the process of performing an activity (Venkatesh et al. , 2003).

9. Affect toward use $(\mathrm{X} 8.3, \mathrm{X} 7.1, \mathrm{X7.2}$, and $\mathrm{X7.3})$ refers to a feeling of joy (X4.2) or a happy feeling, pleasure, or elation; depression, disgust, displeasure associated by an individual with a particular act (Thompson et al., 1991).

10. Compatibility (X1.3) is explained as prospective users' perception of the innovation's alignment with the needs and beliefs (Kaur, Dhir, Bodhi, Singh, \& Almotairi, 2020).

11. Subjective norms (X3.1) are described as the person's perception that should or should not do the behavior in question (Venkatesh et al., 2003).

12. Social factors (X3.2). The social cause is the degree of trust the relevant persons have for using the system (Venkatesh et al., 2003). 


\section{Hypothesis Development}

Preference is a process of ranking all things consumed to get a certain tendency in a product or service, according to Frank (2006). As stated by Laksana, Astuti, and Dewantara (2015), perception is the process of finding information through sensing tools, which are then selected, organized, and interpreted to become a meaningful picture. Each person can choose the most preferred product from the available alternatives. Consumers can evaluate products from the information that has been obtained previously from other people so that they can make product ratings (Al Basya, Mawardi, \& Nuralam, 2018). This research was conducted to find the preferences and perceptions of the use of mobile payments. Many factors were discovered from various aspects of the perceptions and preferences of earlier studies. This research delved deeper into all aspects of consumer choice.

$R Q$ : Exploring the consumer's preferences and perceptions of the mobile payments.

\section{Research Methods}

This study used a factor analysis method to answer the research objectives. This factor analysis aimed to summarize and reduce existing information on the initial variables into a new factor dimension. Researchers identified the dimensions of a structure and then determined to what extent each variable could be explained by each dimension using factor analysis. The factor analysis referred to in this study was confirmatory factor analysis (CFA). This factor analysis was employed to test a concept or theory about the theoretical grouping of variables. Besides, the sampling technique in this study was determined based on non-probability sampling. Sampling was done using purposive sampling. The sample is limited to a specific population that can provide the required information or a population based on the researcher's criteria (Sekaran \& Bougie, 2014). The sample chosen was mobile payment users in three major cities in Indonesia: Surabaya, Jakarta, and Yogyakarta. The primary data were used in this study. Meanwhile, data collection was carried out by distributing as many as 120 questionnaires to respondents, according to a predetermined number of samples. However, it was found that one respondent did not take the questionnaire seriously, so it was decided not to use the questionnaire. The samples were said to be feasible according to Roscoe in Suki (2013), affirming that the number of samples said to be eligible is 30-500. Further, the questionnaire contained a statement that described the variables studied.

\section{Results and Discussion}

Based on this study's main criteria, respondents were mobile payment users and respondents residing in Surabaya, Jakarta, or Yogyakarta, with a total of 119 respondents found in this study. Based on gender, there were 48 men and 71 women respondents. Judging from the respondents' domicile, 45 respondents resided in Surabaya, 27 respondents resided in Jakarta, and 47 respondents resided in Yogyakarta. Besides, a 
validity test was done by conducting a convergent validity test, construct a test, and discriminant test. Based on the samples used in this research, the questionnaire's statement items were declared valid if more than 0.50. Based on the KMO and Bartlett's Test values of 0.954 , the instrument was declared valid $(>0.50)$. Judging from the value of Anti Image Correlations, each statement item was stated to form the construct of consumer perception using mobile payment because it has met the criteria, which was $>$ 0.50 . Furthermore, to see how much the construct could explain the factors, it was seen from the number of communalities. The Table 1 shows that the value of X8.4 (0.259) was less than 0.50 , so it could be stated that the item could not explain the factor. Thus, item X8.4 could not be used.

Table 1 Validity Test

\begin{tabular}{|c|c|c|c|c|}
\hline Variable & Indicator & $\begin{array}{c}\text { KMO dan } \\
\text { Bartlett's Test }\end{array}$ & $\begin{array}{l}\text { Anti-Image } \\
\text { Correlations }\end{array}$ & Communalities \\
\hline & $\mathrm{X} 1.1$ & 0,954 & $971^{a}$ & 810 \\
\hline & $\mathrm{X} 1.2$ & & $949^{a}$ & ,850 \\
\hline & $\mathrm{X} 1.3$ & &, $915^{a}$ & 694 \\
\hline & $\mathrm{X} 1.4$ & & ,949a & 687 \\
\hline & $X 2.1$ & & $970^{a}$ & ,782 \\
\hline & $X 2.2$ & & $947^{a}$ & ,819 \\
\hline & $X 2.3$ & &, $970^{a}$ & ,640 \\
\hline & X3.1 & &, $874^{a}$ & 784 \\
\hline & X3.2 & &, $895^{a}$ & ,832 \\
\hline & $X 4.1$ & & $961^{a}$ & ,814 \\
\hline & $X 4.2$ & & $961^{a}$ & 796 \\
\hline & $X 4.3$ & &, $946^{a}$ & 701 \\
\hline & $\times 5.1$ & & $974^{a}$ & ,859 \\
\hline & $X 5.2$ & &, $960^{a}$ & ,802 \\
\hline & $\times 5.3$ & &, $955^{a}$ & ,866 \\
\hline & $\times 5.4$ & &, $962^{a}$ & ,843 \\
\hline & $\times 5.5$ & &, $956^{a}$ & ,825 \\
\hline & $X 5.6$ & & $967^{a}$ & ,883 \\
\hline & X6.1 & &, $962^{\mathrm{a}}$ & ,846 \\
\hline & $\mathrm{X} 6.2$ & &, $956^{a}$ & 781 \\
\hline & $x 6.3$ & &, $956^{a}$ & ,851 \\
\hline & X7.1 & &, $929^{a}$ & 796 \\
\hline & $\mathrm{X} 7.2$ & & $931^{\mathrm{a}}$ & 776 \\
\hline & X7.3 & &, $975^{a}$ & ,855 \\
\hline & $X 8.1$ & &, $967^{a}$ & ,719 \\
\hline & $\mathrm{X} 8.2$ & &, $964^{a}$ & 671 \\
\hline & $\mathrm{X} 8.3$ & &, $962^{\mathrm{a}}$ & ,814 \\
\hline & $\mathrm{X} 8.4$ & &, $924^{a}$ & ,259 \\
\hline
\end{tabular}

\section{Factor Extraction Results}

The number of factors formed was determined by the eigenvalue. If the eigenvalue $>1$, it will form a new factor. Meanwhile, if the eigenvalue $<1$, it is stated that no new factor is formed. From the Table 2, it can be seen that three new factors were formed, with the eigenvalues, namely factor $1(18,924)$, factor $2(1,403)$, and factor $3(1,327)$. The indicators that made up the new factor can be seen from the Matrix Component value. It could be done after the number of factors formed was known. The Matrix Component value must be $\geqslant 0.60$ (based on the number used in the varimax method). From the three new factors formed, it was found that factor 1 was formed from 12 indicators, namely X1.2, X5.1, X5.2, X5.6, X1.1, X4.1, X2.2, X5.3, X4. 2, X5.5, and X2.1. Factor 2 was formed from 
nine indicators, namely X6.2, X6.3, X6.1,X7.1,X7.3,X7.2, X8.3, X8.1, and X2.3. Meanwhile, factor 3 was formed from three indicators, namely X3.2, X3.1, and X1.3.

Table 2 Eigen Value

\begin{tabular}{ccc}
\hline Factors & Total & Eigen value \\
& 18,924 & \% of Variances \\
\hline 1 & 1,403 & 67,585 \\
2 & 1,327 & 5,010 \\
3 & & 4,739 \\
\hline
\end{tabular}

Table 3 Value of Matrix Components and form factors

\begin{tabular}{|c|c|c|c|c|}
\hline \multicolumn{2}{|c|}{ Factors } & \multicolumn{3}{|c|}{ Form Factors } \\
\hline & & 1 & 2 & 3 \\
\hline \multirow{12}{*}{ Perceive of usefulness } & $\mathrm{X} 1.2$ & 872 & & \\
\hline & $\mathrm{X} 5.1$ & ,824 & & \\
\hline & $\mathrm{X} 5.2$ & ,771 & & \\
\hline & $X 5.4$ & ,767 & & \\
\hline & $X 5.6$ & ,755 & & \\
\hline & $\mathrm{X} 1.1$ & ,747 & & \\
\hline & $X 4.1$ & ,745 & & \\
\hline & $\mathrm{X} 2.2$ & ,739 & & \\
\hline & $\mathrm{X} 5.3$ & ,732 & & \\
\hline & $\mathrm{X} 4.2$ & ,683 & & \\
\hline & $\mathrm{X} 5.5$ & 656 & & \\
\hline & $\mathrm{X} 2.1$ & ,641 & & \\
\hline \multirow[t]{9}{*}{ Behavior to use } & $\mathrm{x} 6.2$ & & ,838 & \\
\hline & $\mathrm{x} 6.3$ & & ,804 & \\
\hline & $x 6.1$ & & ,784 & \\
\hline & $\mathrm{X} 7.1$ & & ,733 & \\
\hline & $\mathrm{X} 7.3$ & & ,703 & \\
\hline & $x 7.2$ & & 674 & \\
\hline & $\mathrm{X} 8.3$ & & ,641 & \\
\hline & $\mathrm{X} 8.1$ & & 624 & \\
\hline & $\mathrm{X} 2.3$ & & ,621 & \\
\hline \multirow{3}{*}{ Self-efficacy } & $\mathrm{X} 3.2$ & & & ,806 \\
\hline & X3.1 & & & ,795 \\
\hline & $\mathrm{X} 1.3$ & & & 673 \\
\hline
\end{tabular}

Some of the factors that shaped the perception of the use of mobile payments in Indonesia are:

1. Factor 1 , called the perceived ease-of-use.

Perceived usefulness is the level of someone's belief that technology can improve performance (Yani, Lestari, Amalia, \& Puspita, 2018). Several previous studies have proven that ease of perception has an influence on the attitude of the use of technology, including research conducted by Ramdani, Kawalek, and Lorenzo (2009). Besides that, Dalcher and Shine (2003) state that perceived usefulness is a construct of one's belief that the use of a specific technology will be able to improve their performance. Ease is very influential on the behavior of the use of Financial Technology system and has a quite high influence on the interest in using electronic money/ Cashless Payment (Kamil, 2020). Perceived usefulness is also defined as a prospective assessment (good hope) that comes 
from a personal point of view, where using specific application systems will improve the quality of work and the quality of life; the belief that using applications will improve one's performance (Surendran, 2012). Perceived usefulness is the extent to which a person believes that using technology will improve performance (Chauhan, 2015). Perceive of ease of use or perceived usefulness in this study was formed from several indicators, including perceived behavioral control (X1.1 and X1.2), perceived usefulness (X2.1), extrinsic motivation (X2.2), individual preferences (X4.1), joy (X4.2), perceived ease of use (X5.1, X5.2, and X5.3), and ease of use (X5.5 and X5.6).

\section{Factor 2, called intention to use.}

A person's interest in doing a particular behavior is called behavioral intention to use. Interest is related to behaviors or actions, but interest can change with time; the wider the time interval, the more likely a person's interest changes (Yani et al., 2018). Chauhan (2015) defines behavioral intention to use as the level of how strong a person's desire or urge is to perform certain behaviors. Intention to use or referred to as usage behavior, in this study, the use of mobile payments was formed from several indicators: job-fit (X2.3), usage behavior (X6.1), intention to use system (X6.2 and X6.3), happiness (X7.1 and X7.3), processes (X7.2), intrinsic motivation (X8.1), and affect toward use (X8.3).

\section{Factor 3, called mobile payment self-efficacy.}

Dory, Beaulieu, Pestiaux, Pouchain, Gay, Rocher, and Boucher (2009) define that selfefficacy represents how a user understands and believes in skills and his ability to complete a task. Robbins and Coulter (2014) explain self-efficacy as an individual's belief in the capability of completing the task, where the higher the individual's self-efficacy, the more confidence in the ability to complete the task. Then, mobile payment self-efficacy was formed by the following indicators, namely compatibility (X1.3), subjective norms (X3.1), and social factors (X3.2).

Succeeding Zamroni's (2006), the factors that influence perception include motives, willingness and expectations, stimulation intensity, and repetition. Meanwhile, the indicators that build ease of use perceptions are perceptions of behavioral control, perceived usefulness, extrinsic motivation, individual preferences, joy, and perceived ease of use. This result in line with research conducted by McLeod and Pippin (2012). The intention to use technology comes from three aspects: the influence of superiors and colleagues, perceptions of technology performance, and technology facilities. The case in this study was that mobile payment users would perceive mobile payments as an easy-touse medium. Similarly, the behavior research of Giovanis, Binioris, and Polychronopoulos (2012) states that consumer behavior towards the use of M-Banking was determined by three M-Banking attributes assessed rationally (usability, convenience, and compatibility).

Furthermore, the intention to use mobile payments in Indonesia also shapes mobile payment users' perceptions. Some indicators that form an intention to use are job-fit, usage behavior, intention to use the system, happiness, processes, intrinsic motivation, 
and influence on usage. Based on the research results by Rahi and Abd. Ghani (2019), overall website design, performance expectations, guarantees, customer service, business expectations, reliability, social influence, and facilitation conditions explained the intention of internet users to adopt internet banking. In this study, the intention to use mobile payment was supported by indicators of usage behavior, intention to use the internet, intrinsic motivation, and influence on behavior.

The third factor formed is self-payment self-efficacy. According to Venkatesh et al. (2003), self-efficacy comes from the SCT theory, which is defined as assessing a person's ability to use technology (e.g., computers) to complete specific jobs or tasks. Based on previous research conducted by Chao (2019), it was found that the mobile payment research model is unique because it integrates perceptions of enjoyment, self-efficacy, satisfaction, and trust to evaluate user determinants. Thus, it could also be concluded that mobile payment's self-efficacy, which was formed from the compatibility indicator of mobile payment, subjective norms, and social factors, became consumers' perception of mobile payment. Further, research development can be done by adding variables or expanding existing financial technology objects. Plus, with the current pandemic conditions, consumers can make mobile payment as a safe payment tool. Small businesses can also make this research a basis for considering mobile payment use based on consumer preferences and perceptions.

According to Frank (2006), preference is the process of ranking all things that can be consumed to get a certain tendency in a product or service. Based on the description of consumer preferences for a product, then the perception of the use of mobile payment in Indonesia is determined from the variables contained in the UTAUT model (Bhatiasevi, 2016; Singh et al., 2017).

Meanwhile, consumer preferences could be seen from the tendency of respondents' answers to the indicators chosen by consumers. This consumer preference was seen from the comparison of Cronbach's Alpha with Cronbach's Alpha if Item0Deleted; if Cronbach's Alpha ifOltem Deleted is greater than Cronbach'sOAlpha, then it can be concluded that the item is more important than other items. While the value of std. deviation was to see the similarity of these items; the higher the std. deviation, the more different or diffused the respondent's answer, but the smaller, the more similar the respondent's answer. When viewed from the comparison of Cronbach's alphaOvalues with Cronbach's0alpha if item deleted, it was found that several indicators became consumers' preferences in using mobile payments: compatibility (X1.3), job-fit (X2.3), subjective norms (X3.1), social factors (X3.2), perceived ease of use (X5.1), usage behavior (X.6.2), and happiness (X7.3). Mobile payment users chose mobile payment preferences according to their needs, ease of use, productivity, social-environmental influences, and happy feelings when using mobile payments. According to Laksana et al. (2015), perception is the process of finding information through sensing tools that are then selected, organized, and interpreted to become a meaningful picture. Consumers' perceptions of the use of mobile payments were indicated by the formation of three factors from the factor analysis results. According to research by Di Pietro, Guglielmetti Mugion, Mattia, Renzi, \& Toni (2015), the use of cell phones for financial transactions has encouraged the development of various 
payment systems. The use of the internet is vital in processing payments for products and services. Promotional activities must be undertaken to enhance service awareness of the targeted audience, highlight the similarities between new technology's capabilities and individuals' current and preferred work practices and underscore how the new technology embodies customers' values (Giovanis et al., 2012).

\section{Conclusion}

Mobile payments are growing rapidly nowadays in terms of benefits, each of which has its advantages. In this case, preference is a process of ranking things consumed to obtain a trend towards a product or service according to Frank (2006). According to Laksana et al. (2015), perception is the process of finding information through sensing tools, which is then selected, organized, and interpreted to become a meaningful picture. Based on perception, three factors were formed that most influence the use of mobile payments: intention to use, perceived ease of use, and self-efficacy. Based on the preferred aspect, perceived ease of use and perceived behavior control factors most influenced consumers in using mobile payments. In fact, communication is a human need as a social being and himself. The process of delivering messages by utilizing technology is highly dependent on people's experiences and behaviors. Besides, mobile payment is currently a necessity that can facilitate human activities. The covid-19 pandemic has also prompted the need for mobile payments. Increasing public awareness has led to an increase in the use of cashless payments.

\section{References}

Al Basya, M.F.Y., Mawardi, M.K., \& Nuralam, I.P. (2018). Analisis preferensi konsumen terhadap keputusan menggunakan jasa kursus bahasa inggris (Studi pada pelanggan lembaga kursus bahasa inggris di Kampung Inggris Pare). Jurnal Administrasi Bisnis (JAB), 58(2), 197-205. Retrieved from

http://administrasibisnis.studentjournal.ub.ac.id/index.php/jab/article/view/2447

Alfany, Z., Saufi, A., \& Mulyono, L.E.H. (2019). The impact of social influence, self-efficacy, perceived enjoyment, and individual mobility on attitude toward use and intention to use mobile payment of OVO. Global Journal of Management and Business Research,. 19(7), 18 , Retrieved from https://journalofbusiness.org/index.php/GJMBR/article/view/2951

Bhatiasevi, V. (2016). An extended UTAUT model to explain the adoption of mobile banking. Information Development, 32(4), 799-814.

https://doi.org/10.1177/0266666915570764

Bruggink, D. \& Mouilleron, E. (2016). Interview success factor for the deployment of financial technology: An Interview with Eric Mouilleron. Journal of Payments Strategy and Systems, 10(4), 396-400.

Campenon, B. (2016). Quasi-experimentation: Design and analysis issues for field settings. Boston MA: Houghton Mifflin Co.

Chao, C.-M. (2019). Factors determining the behavioral intention to use mobile learning: An application and extension of the UTAUT model. Frontiers in Psychology, 10. https://doi.org/10.3389/fpsyg.2019.01652 
Chauhan, S. (2015). Acceptance of mobile money by poor citizens of India: Integrating trust into the technology acceptance model. Info, 17(3), 58-68. https://doi.org/10.1108/info-02-2015-0018

Dalcher, I., \& Shine, J. (2003). Extending the new technology acceptance model to measure the end user information systems satisfaction in a mandatory environment: A Bank's Treasury. Technology Analysis and Strategic Management, 15(4), 441-455. https://doi.org/10.1080/095373203000136033

Davis, F. D. (1989). Perceived usefulness, perceived ease of use, and user acceptance of information technology. MIS Quarterly, 13(3), 319-340. https://doi.org/10.2307/249008

Di Pietro, L., Guglielmetti Mugion, R., Mattia, G., Renzi, M. F., \& Toni, M. (2015). The Integrated Model on Mobile Payment Acceptance (IMMPA): An empirical application to public transport. Transportation Research Part C: Emerging Technologies, 56, 463-479. https://doi.org/10.1016/i.trc.2015.05.001

Dory, V., Beaulieu, M.-D., Pestiaux, D., Pouchain, D., Gay, B., Rocher, G., \& Boucher, L. (2009). The development of self-efficacy beliefs during general practice vocational training: An exploratory study. Medical Teacher, 31(1), 39-44. https://doi.org/10.1080/01421590802144245

Frank, R. H. (2006). Microeconomics and Behavior. Eighth edition, Mc.Graw. Hill International Edition

Giovanis, A. N., Binioris, S., \& Polychronopoulos, G. (2012). An extension of TAM model with IDT and security/privacy risk in the adoption of internet banking services in Greece. EuroMed Journal of Business, 7(1), 24-53. https://doi.org/10.1108/14502191211225365

Hastomo, A. D., \& Aras, M. (2018). Influence of cashless society socialization toward trust transaction culture in Jakarta, Indonesia. Humaniora, 9(1), 1-13. https://doi.org/10.21512/humaniora.v9i1.4174

Hogarth, J. M. (2002). Financial literacy and family and consumer sciences. Journal of Family and Consumer Sciences: From Research to Practice, 94(1), 14-28. Retrieved from https://eric.ed.gov/?id=EJ638619

Juhri, K., \& Dewi, C. K. (2017). Kepercayaan dan penerimaan layanan mobile money t-cash di Bandung dengan pendekatan Technology Acceptance Model (TAM). Jurnal Pro Bisnis, 10(1), 36-51. Retrieved from https://ejournal.amikompurwokerto.ac.id/index.php/probisnis/article/view/503

Kamil, I. (2020). Cashless Society: The effect of financial ability, ease and security on behavior of the use of financial technology system. Asian Journal of Economics, Business and Accounting, 46-58. https://doi.org/10.9734/ajeba/2020/v20i330328

Kaur, P., Dhir, A., Bodhi, R., Singh, T., \& Almotairi, M. (2020). Why do people use and recommend $\mathrm{m}$-wallets? Journal of Retailing and Consumer Services, 56. https://doi.org/10.1016/i.jretconser.2020.102091

Laksana, G. B. Astuti, E.S. \& Dewantara, R.Y. (2015). Pengaruh persepsi kemanfaatan, persepsi kemudahan penggunaan, persepsi resiko dan persepsi kesesuaian terhadap minat menggunakan mobile banking. Jurnal Administrasi Bisnis (JAB). 26 (2). 1-8. Retrieved from http://administrasibisnis.studentjournal.ub.ac.id/index.php/jab/article/view/1066

Manik, T. (2019). Analisis pengaruh transaksi digitalisasi uang elektronik terhadap cashless society dan infrastruktur uang elektronik sebagai variabel pemodarasi. Jurnal Ilmiah Akuntansi dan Finansial Indonesia, 2(2), 27-40. https://doi.org/10.31629/jiafi.v2i2.1714

Marakarkandy, B., Yajnik, N., \& Dasgupta, C. (2017). Enabling internet banking adoption: An empirical examination with an augmented technology acceptance model (TAM). 
Journal of Enterprise Information Management, 30(2), 263-294.

https://doi.org/10.1108/jeim-10-2015-0094

Mardiana, S., Tjakraatmadja, J. H., \& Aprianingsih, A. (2015). Validating the conceptual model for predicting intention to use as part of information system success model: The case of an indonesian government agency. Procedia Computer Science, 72, 353-360. https://doi.org/10.1016/i.procs.2015.12.150

McLeod, A., \& Pippin, S. (2012). Tax software acceptance: how do professional users differ from novices? International Journal of Business Information Systems, 10(3), 312-327. https://doi.org/10.1504/ijbis.2012.047533

Park, K. (1998). Innovative product usage behavior in the post-adoption process. Asia Pacific Advances in Consumer Research, 3, 107-112. Retrieved from https://www.acrwebsite.org/volumes/11560

Rahi, S., \& Abd. Ghani, M. (2019). Integration of expectation confirmation theory and selfdetermination theory in internet banking continuance intention. Journal of Science and Technology Policy Management, 10(3), 533-550. https://doi.org/10.1108/jstpm-06-2018$\underline{0057}$

Ramdani, B., Kawalek, P. \& Lorenzo, O. (2009). Predicting SMEs' adoption of enterprise systems. Journal of Enterprise Information Management, 22(1/2), 10-24. https://doi.org/10.1108/17410390910922796

Robbins, S. P., \& Coulter, M. (2014). Management (12th-ed). Boston: Pearson.

Sekaran, U., \& Bougie, R. (2014). Research Methods for Business: A Skill-Building Approach, 6th Edition. Chichester: John Wiley \& Sons Ltd.

Shin, D.-H. (2009). Towards an understanding of the consumer acceptance of mobile wallet. Computers in Human Behavior, 25(6), 1343-1354. https://doi.org/10.1016/j.chb.2009.06.001

Singh, N., Srivastava, S., \& Sinha, N. (2017). Consumer preference and satisfaction of Mwallets: a study on North Indian consumers. International Journal of Bank Marketing, 35(6), 944-965. https://doi.org/10.1108/ijbm-06-2016-0086

Suki, M. N. (2013). Green awareness effects on consumer's purchase decision: Some insights from Malaysia. IJAPS, 9(2), 49-63. Retrieved from https://ijaps.usm.my/?page id $=1937$

Surendran, P. (2012). Technology acceptance model: A survey of literature. International Journal of Business and Social Research (IJBSR), 2(3), 175-178. Retrieved from https://thejournalofbusiness.org/index.php/site/article/view/161

Venkatesh, V., Morris, M.G., Davis, G.B., \& Davis, F.D. (2003). User acceptance of information technology: Toward a unified view. MIS Quarterly, 27(3), 425-478. https://doi.org/10.2307/30036540

Widdowson, D., \& Hailwood, K. (2007). Financial literacy and its role in promoting a sound financial system. Reserve Bank New Zealand Bull. 70, 37-47.

https://www.rbnz.govt.nz/research-and-publications/reserve-bankbulletin/2007/rbb2007-70-02-04

Yani, E., Lestari, A. F., Amalia, H., \& Puspita, A. (2018). Pengaruh internet banking terhadap minat nasabah dalam bertransaksi dengan technology acceptance model. Jurnal Informatika, 5(1), 34-42. https://doi.org/10.31311/ii.v5i1.2717

Zamroni, A. (2016). Pengaruh citra merek, kualitas produk dan promosi terhadap keputusan pembelian produk pepsodent pada konsumen indomaret plus di jalan M. Yamin Samarinda. Journal Administrasi Bisnis, 4 (4), 960-974. Retrieved from https://www.portal.fisip-unmul.ac.id/site/?p=5276 